\title{
Analysis of the Characters in The Sacred Book of the Werewolf
}

\author{
Jiarui Hu1 ${ }^{*}$, Ying Tian ${ }^{2}$ \\ ${ }^{1}$ Faculty of Arts, People's Friendship University of Russia, Moscow 117198, Russia \\ ${ }^{2}$ Kunming Hi-Tech Industrial Development Zone No.3 Middle School, Kunming 650503, China \\ *Corresponding author: Jiarui Hu, hujch@139.com
}

\begin{abstract}
The Sacred Book of the Werewolf is a masterpiece of Russian postmodernism literature, which is filled with magic features, oriental and occidental religions, as well as cultural symbols. The author depicts a series of expressive characters in almost acerbic descriptions. Especially when the oriental elements in foxes from China encounter the occidental elements in wolves from the West; the collision of the two cultures is obvious, which portrays all living creatures during the end of the Soviet Union and Contemporary Russia.
\end{abstract}

Keywords: The Sacred Book of the Werewolf; Postmodernism literature; Pelevin; Fox; Werewolf

Publication date: November 2021; Online publication: November 30, 2021

\section{Introduction}

Victor Pelevin (Виктор Пелевин) is a popular writer in contemporary Russian literary circles. He is known as the representative of contemporary Russian postmodernism literature. The famous French literary magazine, French Magazine, placed him on the list as one of the 1,000 most influential writers in the world today. His masterpieces that are filled with magic features, oriental and occidental religions, cultural symbols, as well as time-travelling fantasies have not only been well-received and translated into many languages but also adapted into dramas and operas to be staged in France and the United Kingdom, such as Omon Ra, The Prefect of the Soviet Union, The Story of Insects, The Pepsi Generation, Buddha's Little Finger, Yellow Arrow, The Sacred Book of the Werewolf, and so on. Pelevin pointed out current malpractices in a joking and hyperbolic manner to portray all living creatures during the end of the Soviet Union and Contemporary Russia.

\section{Pelevin and the synopsis of The Sacred Book of the Werewolf}

Pelevin's works are not limited only to native Russian culture, but they include the history and religions in Europe, America, China, Japan, and other Asian countries. For example, a lot of cultural elements have been quoted in his novel, The Pepsi Generation, such as European and American movies, popular songs, Bible stories, Forbes Magazine, and even many paragraphs narrated directly in English (Russian remarks are added below). It also embodies Chinese religions - Buddhism and Taoism, citing the story of Zhuang Zhou's Dream of Turning into a Butterfly (a Chinese fairytale) and the Buddhism's theory of "All is Vanity," in the novel to clearly depict Russia's past and present as well as to find a way out for the confused contemporary Russians.

The Sacred Book of the Werewolf ${ }^{[1]}$ was written in 2004, which tells a story of a hetaera named A Hu$\mathrm{Li}$, who is being forced to earn her living by prostitution in Moscow. According to her own words, born in 
China and being more than two thousand years old, she believes she is the relative of the Monkey King. What has been changing is her heart, and not her appearance. The only little change is the white hair that grows on her tail every 180 years.

Her name had no meaning in the Russian language; the name was given by a Chinese scholar more than 2,000 years ago. Her sisters - E Hu-Li, also lives in Moscow, and U Hu-Li lives in Thailand. Sasha, a Russian lieutenant general enlisted with the Federal Security Service, whom A Hu-Li fell in love with, is not a human, but a werewolf. He often turned into a wolf while being in a relationship with A Hu-Li. While they got closer, Sasha began turning into a black dog unalterably. Being shameful but still eager to work in the Ministry of Internal Affairs, he ended the relationship and went to the far north.

At the end of the story, Sasha came back to find A Hu-Li and proposed to her, but she was noncommittal. Finally, A Hu-Li acquired a way to immortality; that is, true love, so as to experience real spiritual release.

\section{Relationship between the image of the fox, $\mathrm{A} \mathrm{Hu}-\mathrm{Li}$, in The Sacred Book of the Werewolf and the image of the fox spirit in Chinese mythology}

In Chinese mythology, the legend of foxes turning into demons has been ongoing for a long time. The Classic of Mountains and Rivers ${ }^{[2]}$, written during the Spring and Autumn period as well as the Warring States period, mentioned, "There is a beast in the mountains of Qingqiu, whose shape is like a fox with nine tails, and whose voice sounds like an infant. The beast eats people to prevent harm from perverse trend." Fox represents cleverness and cunningness in Chinese ancient legends. Pelevin also portrayed the fox as smart and astute in his book. For instance, the fox is proficient in almost "any kind of language" and all kinds of knowledge, such as mathematics, physics, history, literature, and so on.

The book mentioned, "The fox had a keen interest in a book, A Brief History of Time, reading from cover to the cover many times tirelessly with a kind of freshness." A Brief History of Time is a monograph on the laws of cosmic celestial bodies, written by the late British theoretical physicist, Stephen Hawking. For general readers, it is very difficult to understand without certain knowledge of physics, astronomy, and mathematics. Therefore, it shows how clever and knowledgeable the fox is. Besides, she had also extensively studied famous Chinese classics, such as Tao Te Ching, The Analects of Confucius, Anecdotes About Spirits and Immortals, Journey to the West, etc. and was familiar with the sentences written by classic Russian writers, such as Pushkin, Tolstoy, Chekhov, and other literary magnates.

In Anecdotes About Spirits and Immortals, written by Ganbao, during the Eastern Jin Dynasty ${ }^{[3]}$, the beautiful Azi is a fox demon transformed from a thousand-year-old fox, fascinating the warrior, Wang Lingxiao. When Wang's superiors realized that Wang did not attend to his position, they sent someone to look for him. Wang could no longer speak the human language, and his shape was fox-like. Obviously, he was bewitched by the fox demon and already poisoned deeply.

In the Chinese mythology, Creation of the Gods, Su Daji captivated the king of Shang Dynasty with her beauty and acumen, making the king indulge in sultriness, persecute the faithful and honest ferociously, as well as extort excessive taxes and levies mercilessly. This finally led to a revolt by Ji Fa, who engaged a large army to defeat King Zhou and attacked the capital. It was the doom of the Shang Dynasty. Other than that, in Strange Tales from a Chinese Studio ${ }^{[4]}$, compiled by Pu Songling, there are dozens of stories about foxes transforming into beauties to seduce the commoners, extort money, eat humans, and drink their blood, leading to the destruction of many families. In traditional Chinese Taoism, there is a saying - "cai Yin pu Yang," which means to absorb Yin from others or the outside world to balance the opposing Yang and improve self-cultivation. In Pelevin's work, the fox, A Hu-Li can use her own tail to perceive the changes of other people's emotions, just like watching a cartoon and resonating with the consciousness of others, so as to bewitch them and absorb their energy. Just as mentioned in the novel, she often stretches her tail into her guests' body to absorb their energy instead of touching the guests directly, befuddling men's 
consciousness and making them hallucinate. She was keenly aware of the fluctuations and changes of others and the society. At the beginning of her interaction with Sasha, who works with the Federal Security Service, she felt that he was not same as ordinary people. When she noticed that his emotions were frequently out of control with a murderous aura exuding from him, she knew that the lieutenant general is not a normal human being but like her, he is a heterogenous.

As the old saying goes, "People die as ghosts, and things grow so old that they become monsters." In Chinese mythology, there has always been a legend that birds, beasts, plants, flowers, and stones can become immortal human-shaped monsters, such as the White Lady - the thousand-year-old snake spirit, and the thousand-year-old Monkey King. The fox in this work is also endowed with such a Chinese mythological style. A Hu-Li was born in China more than two thousand years ago. What is interesting is that the name, $\mathrm{A} \mathrm{Hu}-\mathrm{Li}$ is completely from Chinese transliteration and has nothing to do with the Russian language.

More than two thousand years ago, a Confucian disciple was surprised to see the fox and bestowed her the name, A Hu-Li. She has two sisters, E Hu-Li and U Hu-Li, who are also millennium fox demons; one of them went to Britain, but the other stayed in China, and then moved to Thailand. Thousands of years ago, A Hu-Li moved to Russia before the establishment of the Russian state. She was more like a spectator and witness of history, experiencing the vicissitudes and great changes of Russia from the perspective of a third party. As a spectator and witness of history, the fox developed a clearer understanding of the development of the land.

For example, in the fox's opinion, Moscow is a scene with building skyscrapers; its people enjoy delicious food and purchase luxury cosmetics as well as clothes from various countries; however, this prosperity has nothing to do with the economy, whereby wealth just flows from all over Russia. "I remember you said that the main contradiction in modern times is the contradiction between money and blood." In Moscow, everyone is losing their blood, but wealth is always in them.

"However, the changes in Russia have always been verbal only, as was the case during the period of Ivan Reid, the first czar of Russia. If Russia is compared to a big fish and these reformers are the head of the fish, their reform measures often remain verbal rather than practical results. These reformers gradually devour the fish's body, and currently, its international image is like an oil pipeline with rats crawling on it, leading to a wasteland covered with ice; Eskimos can have more than 20 proverbs about snow, whereas Russians have only more and not less jokes about bribery and gifts to officials and the police ${ }^{[5]}$."

Through a fox demon as the protagonist, Pelevin expressed his concern about the current situation and future of Russia. It is difficult to change the diseases that have existed in the Russian society for a long time through verbal reforms. The development differences between regions have become greater, the industrial structure has become more and more unbalanced, the gap between the rich and the poor has become much more serious, and people have lost their respect for morality and good values; instead, they are keen to pursue wealth and power. After the disintegration of the Soviet Union, many small and medium-sized cities in Russia experienced economic downturn and population outflow; the towns were deserted and became ghost towns. However, Petersburg in Moscow was developing abnormally. Tsarist Russia went through the Soviet period to contemporary Russia under the climate of increasingly severe bureaucracy, corruption, and abuse of power for personal gain. The author showed his concern and disappointment about the current situation of Russia and expressed his worries for the country as well as the people in hope that Russia may carry out thorough reform, revive, strengthen, and enrich the people, as well as occupy a status in the wave of the changing world without sinking any longer.

In the novel, although A Hu-Li reads extensively, she dismissed the professor who pursued her. The biggest reason is that he had no money. "Money always wins, and even kindness cannot win over evil with the help of money." One of the reasons why she fell in love with the werewolf was because of his generosity; 
he gave her two diamond rings worth more than 20,000 dollars within a short period of time.

"Two identical white boxes contain rings worth eight thousand and fifteen thousand dollars, one of which is made from white gold and the other with diamond. The bigger stone is 0.8 carats, while the smaller one is 0.54 carats. Tiffany! Most importantly, he asked almost nothing of me except for asking me to call him... ${ }^{[6]}$." This shows the author's exposure and satire on the values of material desire and the supremacy of money. People gradually neglect the inner pursuit of virtue and people; instead, they worship money and power, losing themselves in fame. Money and power have become the only measure of a person's success; more and more people are willing to abandon themselves to vice and lose themselves in the vanity fair.

In this work, the author also portrayed the fox's journey from an animal to a fairy. Although she made a living by absorbing men's energy and did many evil things, A Hu-Li increasingly demonstrated human nature and improved herself over thousands of years of practice. During the Eastern Han Dynasty, she used her pseudonym, Azi, to bewitch a warrior, Wang Lingxiao. He lost himself and gradually became a fox. He did not recover for more than ten days. She often lured men, absorbed their essence, and disturbed their minds; however, she felt guilty and condemned herself. In the end, the fox improved, and her love for the werewolf made her realize the power of love and finally gain true freedom, thus escaping the sea of earthly suffering and ascending to become a fairy.

\section{The relationship between the fox and the werewolf reflects the differences in culture and values}

In contrast to the Chinese image of $\mathrm{A} \mathrm{Hu}-\mathrm{Li}$ in the novel, the other protagonist, the werewolf, is one of the spiritual symbols of the Russian nation. In many Russian folklores, wolves are symbols of strength and courage; in battles, wolves would move forward bravely one after another, until death or victory; in addition, many warriors who have died on the battlefield would also turn into wolves and continue to fight in the jungle. In the 16th century, Russian warriors often wore badges with wolf patterns to boost their morale. In this work, Sasha is the projection of Russian political leaders and the Russian national spirit ${ }^{[7]}$.

In the novel, Pelevin portrayed two modes of demon transformation: the first is a gradual transformation from an animal to an adult with human nature, and finally ascends as an immortal, alike A $\mathrm{Hu}-\mathrm{Li}$; the second possibility of demon transformation is through showing their inner animal nature as exemplified by Sasha. He was originally human, but on a trip, he met several people who could turn into wolves at night. With their help, he gained the ability to become a wolf; he took the form of a wolf at night and a human at daytime. In this work, the transformation of a werewolf has been described in great detail: "Sasha stumbled, made a terrible howl, and fell out of his body - like a bud, which opened into a terrible hairy flower in a few seconds. It was a monster, like a man and a wolf. He howled, and his yellow eyes showed a vicious light. At first, I thought his clothes had disappeared, but then I realized that his uniform and trousers had deformed with him: his trunk was covered with gray fur, his hind legs were darker, and you can see uneven marks on them. When I looked at him, my heart was full of fear ${ }^{[8]}$."

This is also the difference between Eastern and Western legends about monsters, which is different from the Chinese legend of "things grow old and become monster." In Russia and Western countries, it is more popular that humans become monsters for some reason, such as vampires, werewolves, and zombies

[9]. For example, in the novel, Twilight Saga, the two protagonists are Edward, a vampire, and Jacob, a werewolf. In The Legend of Cain, the first vampire was recorded in the Old Testament; Cain was cursed by God as an immortal bloodthirsty monster because he killed his brother. In medieval Europe, werewolves are said to be men bitten by wolves, thus turning into wolves on the night of the full moon. In his works, Pelevin often uses the religious, literary, philosophical, pop music, and other elements of different Eastern and Western countries to present readers with a colorful picture of the contemporary Russian society, different from the previous Tsarist Russia and Soviet Union. 
He also casts a bit of freshness and exoticism in his own works, so that readers can appreciate the contradictions and fusions between different cultures and different thoughts.

In the novel, Sasha serves the Russian Federal Security Service. He is not only keen on power, but also full of patriotism. He believes in the Orthodox Church and is determined to serve the Russian people to revitalize the Russian state and society. In a debate with $\mathrm{A} \mathrm{Hu}-\mathrm{Li}$ and her friends, he did not believe that Europe and the international community would selflessly help Russia; rather, the so-called civilized countries would deceive and plunder Russia as before. Sasha is convinced that Russia should explore a path of its own development. His patriotism had deeply touched the fox, who had been wandering around the world for thousands of years without a sense of belonging. The two protagonists were attracted to each other. A Hu-Li caught a chicken and turned into a fox in front of Sasha, so as to bring them closer.

During the interaction, the fox gradually entered the spiritual world of the werewolf. She learned that the werewolf is a true Orthodox Christian and believed that the love existing between them is a sin, as the fox tended to Eastern philosophy and fatalism. The general believes in mankind and hopes for the future of mankind, while the fox denies the kindness and wisdom of mankind. During a date, the fox kissed Sasha, and Sasha lost his original mana and became a black dog, never again a wolf. Sasha was ashamed and distressed because of the change, but the fox accepted it calmly as she felt that Sasha was no longer cold and fierce. She also told Sasha a story about a dog named Galle who rescued Russia, which inspired Sasha again.

Pelevin combined the two images through love between a werewolf from Russia and a fox from China; however, their love ended in tragedy as they parted ways. Sasha's will was to return to the Security Service to serve his country and his people, whereas the fox wanted to improve herself, escaped from the sea of earthly suffering, and become an immortal. He thanked the fox for her love and strength, wanting to use this strength to serve the people and to prosper Russia. Therefore, he left the fox and returned to the Security Service. Later, the fox received news that Sasha has been fighting with the enemies at home and abroad conscientiously, but at the same time, he became inhuman and arbitrary. Sasha portrayed the style of Russian political leaders for hundreds of years, such as Peter the Great, Ekaterina, Putin, etc., whereas the fox showed a more individualistic emotion. She paid more attention to self-improvement and selfachievement. She really loves Sasha but refuses to give up her self-worth. She also portrayed the independence of contemporary women, where women are no longer the attachment of men, and they no longer trap themselves in love and marriage. She adhered to the pursuit of an ideal life and career instead of indulging herself in love, losing herself, and being unable to extricate herself, as the heroine of Anna Karenina did.

\section{Conclusion}

Russian literature has experienced a process from eulogizing heroes and imperial leaders to paying attention to normal people and individual destiny. It adheres to the concept of "literature is humanism" and attaches importance to individual values and emotions, even reflecting social contradictions and problems. Since the birth of the Soviet society in the 1960s and 1970s, the focus of contemporary Russian literature has been on criticizing the current disadvantages and reflecting the problems existing in the Soviet Union and Russian society. The background of the seemingly fantasy science fiction is often only an appearance depicted by the author in the style of exaggeration ${ }^{[10]}$. For example, in Bulgakov's famous work, Heart of a Dog, it seems that it is an absurd surgery to transform a dog into a man as exemplified by the transformation of Sharik into a rogue proletariat, Sarikov. In Buddha's Little Finger, Pelevin introduced the ideas of Taoism and Buddhism and used the seemingly fantastic journey through time and space to warn Russians not to indulge and live in the past as well as lose themselves; instead, they need to put aside their obsessions, learn to keep pace with the times, keep up with the world development trend, and strive to move 
forward.

In The Sacred Book of the Werewolf, Pelevin introduced cultural elements from different countries and the application of Eastern and Western myths as well as legends. Through the story of the Chinese fox demon falling in love with the Russian werewolf, Sasha, it reflects the collision and blending of different cultural values in contemporary Russia as well as his thoughts on the social problems in Russia, such as corruption, bureaucracy, money worship, etc. It shows the diverse value orientations of the Russian society and leads readers to ponder about both Eastern and Western cultures as well as philosophies. In this manner, they would be able to convey their own views of good and evil through continuous self-reflections and behave virtuously to improve and perfect themselves.

\section{Disclosure statement}

The authors declare that there is no conflict of interest.

\section{References}

[1] Pelevin V, 2017, Священная книга оборотня (The Sacred Book of the Werewolf), E-Publishing.

[2] Liu X, 2019, The Classic of Mountains and Rivers, Coal Industry Press, Beijing.

[3] Gan B, 2019, Anecdotes About Spirits and Immortals, Sanqin Publishing House, Xi'an.

[4] Zhang J, 2018, Cultural Interpretation of Vampires and Werewolves in "Twilight Saga" from the Perspective of Postcolonialism. Guilin University of Technology.

[5] Chen L, 2019, The Image of China in Pelevin's Novels. Heilongjiang University.

[6] Wan F, 2015, Research on Female Images in "Creation of the Gods". Shaanxi Institute of Technology.

[7] Liu Y, 2002, A Study on the Image of Fox in Chinese Classical Novels. Shaanxi Normal University.

[8] 2021, The Wolf in the Mythology of the Ancient Slavs. The Magic of Things. https://yandex.ru/turbo/zauber-russ.ru/s/raznoe/volk-v-slavyanskoj-mifologii.html

[9] Pelevin V, Kasyanov A, 2015, The Image of the "Wolf" in the Novel "The Sacred Book of the Werewolf".

[10] Kolmakova O, 2013, Mythological Metamorphosis as a Cultural Code in Russian Prose at the Turn of the XX-XXI Centuries. 